\title{
Effect of Plant Growth Regulator on Red Onion Cultivation from True Seed Shallot (TSS)
}

\author{
Tri Sudaryono \\ Researcher at East Java Assessment Institute for Agricultural Technology \\ Malang, East Java, Indonesia
}

\begin{abstract}
Red onion is one of the strategic horticultural commodities, considering this commodity is very high consumption as a daily spice and fluctuating price. Therefore is not surprising that these commodities are contributing to inflation. Efforts to meet increasing consumption needs, it is necessary to find the right strategy to increase domestic red onion production. One of the strategies considered to increase domestic red onion production is the use of botanical seed (TSS) as a source of seed on shallot cultivation. There are 2 main weaknesses of red onion cultivation with TSS as a source of seeds. The two weaknesses are TSS low growing power, which is naturally only in the 50-60 \% range and the number of tubers produced is less than 3 cloves per plant. In order to solve the problem, research has been done to know the effect of plant growth regulator on the growth and red onion production from TSS and also get the description of red onion farming from TSS and tuber as seed source. The research was conducted from June to November 2017 at BPP Pare, Kediri Regency, East Java. The results showed that the use of young coconut water on TSS obtained red onion plants are able to produce the number of tubers per plant more than 3 cloves. In detail as much as $22.22 \%$ produces the number of tubers range 4-5 per plant; $56.56 \%$ yields 5-6 bulb range; and as much as $22.22 \%$ produces tubers $>6$. As well, wet weight of tubers when harvested weighing more than $99 \mathrm{~g}$ per plant. If converted per hectare, TSS red onion plants treated with young coconut water can produce a range of $30-35$ tons of wet bulb. This production is doubled compared to the production of shallots grown from tubers. Based on the analysis of the farm, red onion from TSS treated with young coconut water gives a profit of $\mathrm{Rp} 224,860,000$ per hectare with $\mathrm{B} / \mathrm{C}$ ratio of 3.397. This profit is more than 1.75 times compared to the profit of red onion tuber farming which is only Rp 93.787.000, with $\mathrm{B} / \mathrm{C}$ ratio of 1,061 .
\end{abstract}

Keywords: Farming Analysis, Growing Power, Growth, Red Onion, TSS, Yield

\section{INTRODUCTION}

Red onion, to date generally cultivated by using tubers as seeds. The weakness of the use of tubers as seeds in red onion farming, the cost of supplying seed tubers is too high, which is about $40 \%$ of the total cost of production [1];[2]. In addition, the quality of the seed tubers is less safe because it almost always brings pathogens such as Fusarium sp., Colletotricum sp., viruses such as Shallot Laten Virus (SLV) and Leak Yellow Stip Virus (LYSV) as well bacteria from the origin of plants that are attacked, thus productivity is low [3];[4].

The weakness of vegetative propagation by tubers can be overcome by propagation through the seeds of the botanical red onion (TSS). Therefore, the use of botanical seeds is one of the alternatives that can be developed to improve the quality of red onion seeds [5]; [6];[7];[8]. Red onions are essentially flowering plants and can be rapidly propagated through

\footnotetext{
Correspondence address:

Tri Sudaryono

Email : trissdr@yahoo.com

Address : East Java Assessment Institute for Agricultural Technology, Malang, Indonesia
}

large quantities of seeds [9]. In Indonesia, propagation of red onion processing through TSS has long been done, but the results have not been applied by many farmers. The cause is a lot of problems encountered in the cultivation of red onions by using botanical seeds [10].

Seeds are one of the factors that determine crop productivity. In addition to using tubers, propagation of red onions can also use botanical seeds (TSS) as a source of seeds. The use of botanical seeds compared with the use of seed tuber (conventional way) has several advantages, that is the number of botanical seed needs is less between $3-6 \mathrm{~kg} / \mathrm{ha}$, while the need for seed tuber ranging from 1 to $1.5 \mathrm{t} / \mathrm{ha}$, storage and distribution of botanical seeds easier and cheaper, produces healthier plants due to pathogen-free botanical seeds, and also produces better quality tubers [11];[12]. In addition, the use of red onion botanical seeds is economically viable as it can increase yields doubled as much compared to conventional use of seed tubers [13].

The use of botanical seeds as seeds has problems related to the number of tubers produced. The botanical seeds on average produce only 1-2 tubers. The low number of 
tubers produced seems to be related to the small number of tillers produced by botanical seeds [14]. Red onion tillers are the development of apical buds that are formed due to loss of apical shoots dominance. The initiation of this shoots occurs after the occurrence of apical meristem cell division. The formation of tillers of red onion seed tubers from botanical seeds is still difficult to do, because tuber formation can't be affected by temperature, spacing and water stress [15]. Therefore, to encourage the more formation of tubers (more than 3 grains), red onion botany seed (TSS) is treated with plant growth regulators. Treatment with plant growth regulators is expected to encourage cell division, and eventually the tubers formed into more.

Red onion cultivation by using botanical seeds can be done through several ways, that is (1) planting of botanical seeds directly in the field/land, (2) seeding of seeds first, (3) making mini tubers ( $<3 \mathrm{~g} /$ tubers) derived from botanical seeds. Planting of botanical seeds directly in the field requires more seeds, ranging from 6-8 $\mathrm{g} / \mathrm{m} 2)$.

The aim of this research is to know the effect of plant growth regulator on growth and production of red onion from TSS and to get the description of red onion farming from TSS and tuber as seed source.

\section{MATERIAL AND METHOD}

The research was conducted at Assessment Institute for Agricultural Technology Pare, Kediri Regency from June to November 2017. Materials needed for the study include TSS Trisula varieties, plant growth regulators consisting of auxin, cytokines, gibberellins and coconut water, as well other supporting materials. Before sowing of TSS was first immersed in a plant growth regulator solution, ie $\mathrm{H} 1$ : auxin + cytokinin mixture with $200 \mathrm{ppm}$ concentration, $\mathrm{H2}$ : auxin + glyberilin mixture with 200 ppm concentration, H3: auksin + cytokinin + giberelin mixture with $200 \mathrm{ppm}$ concentration, and H4: young coconut water. Overnight immersion. Furthermore, TSS sowing in a plastic bag containing a mixture of soil + manure medium with a ratio of 1: 1. Each bag of seedbed is filled with 1 of TSS.

Move cropping is done when the seeds are 6 weeks old. Planting in the field using a randomized block design with treatment of plant growth regulator $(\mathrm{H} 1 / \mathrm{H} 2 / \mathrm{H} 3 / \mathrm{H} 4)$ and repeated for 6 times. Plot size/plot is $25 \mathrm{~m} 2$ (population of about 1,200 stems, with spacing of $12.5 \mathrm{~cm} \times 15$ $\mathrm{cm})$. Before the seedlings are planted, the seed tip/root is first immersion into the plant growth regulator in accordance with the treatment $(\mathrm{H} 1 / \mathrm{H} 2 / \mathrm{H} 3 / \mathrm{H} 4)$ for 1 hour. Plant maintenance following recommendation [16].

Observations included vegetative growth component (number of leaves, plant height) and generative growth component (number of tillers), and during harvest observation of yield components, ie number of tubers and tubers weight. Also conducted economic analysis of red onion farming from botanical seed (TSS) compared with tubers origin. At the time of transferring seeds from TSS, with the same extent done the planting of red onions from the tubers simultaneously. At each stage of cultivation activities, both derived from TSS and bulbs are recording for aspects of labor and economy.

\section{RESULT AND DISCUSSION}

\section{Plant Growth}

Statistical analysis showed that giving of plant growth regulator in seeds from TSS take effect to plant growth, including plant height, number of leaves and number of stems. The effect of plant growth regulator on plant height, number of leaves and number of shallot stems are shown in Tables 1, 2 and 3 respectively.

In Tables 1, 2 and 3 it appears that the growth of shallot plants from TSS treated with coconut water ( $\mathrm{H} 4$ treatment) is the best vegetative demonstration. TSS treated with coconut water produces shallots with more leaves and stems and higher plants than TSS treated with other growth regulators. The result of this research is correspending with Tiwery which concludes from his research that coconut water giving effect to the growth of mustard plant, especially to growth component, that is plant height and number of leaves [17]. That coconut water affects the growth of female palm seedlings, especially on plant height, leaves length and root length [18]. This fact provides an illustration that coconut water is capable to stimulate plant growth. Therefore, giving of coconut water in plant propagation is used to stimulate the formation of shoots and roots, because coconut water contains of auxin, cytokinin and giberelin hormones, which can trigger cell plant division [19]. Coconut water not only contains growth hormones of auxin, cytokinin and giberelin, but also other complex compounds that contribute to trigger the growth of plants [20]. In this research used young 
coconut water as plant growth regulator $(\mathrm{H} 4$ treatment). It turns out that young coconut water contains not only vitamins and minerals [19], and also growth hormone of auxin, cytokines and gibberellins with sufficient concentration [20]. Young coconut water contains auxin hormone in the form of IAA with a concentration of about $0.237 \mathrm{ppm}$; cytokinin in the form of kinetin with $0,441 \mathrm{ppm}$ concentration and in zeatin form with 0,247 ppm concentration; and gibberellins in the form of
GA3, GA5 and GA7 with concentrations of 0.460 ppm; 0.255 ppm; 0.053 ppm [20]. That young coconut water also contains minerals that function as nutrients. Minerals or nutrients contained in young coconut water are nitrogen $(\mathrm{N})$, phosphorus $(\mathrm{P})$, potassium $(\mathrm{K})$, magnesium $(\mathrm{Mg})$, iron (Fe), sodium ( $\mathrm{Na}$ ) and calcium ( $\mathrm{Ca})$. Therefore it is not surprising, if the red onion plants from TSS treated with coconut water ( $\mathrm{H} 4$ treatment) show the most optimal plant growth [19];[20].

Table 1. Effect of plant growth regulator on plant height red onions from TSS at 1, 2, 3, 4 and 5 Weeks After Moving Planting (WAMP)

\begin{tabular}{cccccc}
\hline \multirow{2}{*}{ Treatment } & & & Plant Height (cm) & \\
& 1 WAMP & 2 WAMP & 3 WAMP & 4 WAMP & 5 WAMP \\
\hline $\mathrm{H}_{1}$ & $24,64 \mathrm{~b}$ & $28,26 \mathrm{~b}$ & $32,20 \mathrm{~b}$ & $34,93 \mathrm{~b}$ & $50,03 \mathrm{~b}$ \\
$\mathrm{H}_{2}$ & $34,74 \mathrm{a}$ & $42,32 \mathrm{a}$ & $44,41 \mathrm{a}$ & $34,76 \mathrm{~b}$ & $37,04 \mathrm{~b}$ \\
$\mathrm{H}_{3}$ & $22,43 \mathrm{~b}$ & $28,63 \mathrm{~b}$ & $31,70 \mathrm{~b}$ & $51,66 \mathrm{a}$ \\
$\mathrm{H}_{4}$ & $35,64 \mathrm{a}$ & $41,59 \mathrm{a}$ & $44,49 \mathrm{a}$ & $48,22 \mathrm{a}$ \\
\hline
\end{tabular}

Information: The numbers in the same column accompanied by the same letter indicate not significantly different based on BNT test $5 \%$

Table 2. Influence of plant growth regulator on the number of plant leaves red onion from TSS at 1, 2, 3, 4 and 5 weeks after moving planting (WAMP)

\begin{tabular}{|c|c|c|c|c|c|}
\hline \multirow{2}{*}{ Treatment } & \multicolumn{5}{|c|}{ Number of leaves (strands) } \\
\hline & 1 WAMP & 2 WAMP & 3 WAMP & 4 WAMP & 5 WAMP \\
\hline $\mathrm{H}_{1}$ & $2,29 \mathrm{~b}$ & $3,32 \mathrm{~b}$ & $4,53 \mathrm{~b}$ & $5,72 b$ & $6,98 \mathrm{~b}$ \\
\hline $\mathrm{H}_{2}$ & $4,48 \mathrm{a}$ & $6,53 \mathrm{a}$ & $8,73 \mathrm{a}$ & $11,01 \mathrm{a}$ & 13,89 a \\
\hline $\mathrm{H}_{3}$ & $2,28 \mathrm{~b}$ & $3,31 \mathrm{~b}$ & $4,38 \mathrm{~b}$ & $5,63 \mathrm{~b}$ & $6,96 \mathrm{~b}$ \\
\hline $\mathrm{H}_{4}$ & $4,47 a$ & $6,74 a$ & $9,00 \mathrm{a}$ & $11,44 \mathrm{a}$ & 15,92 a \\
\hline
\end{tabular}

Information: The numbers in the same column accompanied by the same letter indicate not significantly different based on BNT test $5 \%$

Table 3. Effect of plant growth regulator on the number of plant stems red onion from TSS at 2, 3, 4 and 5 weeks after moving planting (WAMP)

\begin{tabular}{ccccc}
\hline \multirow{2}{*}{ Treatment } & 2 WAMP & 3 WAMP & 4 WAMP & 5 WAMP \\
\hline $\mathrm{H}_{1}$ & $1,29 \mathrm{~b}$ & $1,55 \mathrm{c}$ & $2,09 \mathrm{~b}$ & $2,59 \mathrm{c}$ \\
$\mathrm{H}_{2}$ & $2,87 \mathrm{a}$ & $3,36 \mathrm{~b}$ & $4,38 \mathrm{a}$ & $5,24 \mathrm{~b}$ \\
$\mathrm{H}_{3}$ & $1,27 \mathrm{~b}$ & $1,69 \mathrm{c}$ & $2,47 \mathrm{~b}$ & $3,13 \mathrm{c}$ \\
$\mathrm{H}_{4}$ & $3,04 \mathrm{a}$ & $3,88 \mathrm{a}$ & $5,09 \mathrm{a}$ & $6,07 \mathrm{a}$ \\
\hline
\end{tabular}

Information: The numbers in the same column accompanied by the same letter indicate not significantly different based on BNT test $5 \%$

Table 4. Effect of growth regulator on red onion yield red from TSS

\begin{tabular}{ccc}
\hline \multirow{2}{*}{ Treatment } & $\begin{array}{c}\text { Number of tubers per plant } \\
\text { (clove) }\end{array}$ & $\begin{array}{c}\text { Outcome component bulb weight per plant } \\
\text { (gr) }\end{array}$ \\
\hline $\mathrm{H}_{1}$ & $2,43 \mathrm{C}$ & $46,71 \mathrm{~b}$ \\
$\mathrm{H}_{2}$ & $4,47 \mathrm{~b}$ & $97,29 \mathrm{a}$ \\
$\mathrm{H}_{3}$ & $2,63 \mathrm{C}$ & $45,32 \mathrm{~b}$ \\
$\mathrm{H}_{4}$ & $5,73 \mathrm{a}$ & $99,43 \mathrm{a}$ \\
\hline
\end{tabular}

Information: The numbers in the same column accompanied by the same letter indicate not significantly different based on BNT test $5 \%$ 
Table 5. Percentage of number of tubers 3, 4, 5, 6 and more 6 cloves based on the treatment of plant growth regulator

\begin{tabular}{|c|c|c|c|c|}
\hline \multirow{2}{*}{$\begin{array}{c}\text { Criteria number } \\
\text { of tubers }\end{array}$} & \multicolumn{4}{|c|}{$\begin{array}{l}\text { Percentage (\%) } \\
\text { Based on the treatment of plant growth }\end{array}$} \\
\hline & $\mathrm{H}_{1}$ & $\mathbf{H}_{2}$ & $\mathrm{H}_{3}$ & $\mathrm{H}_{4}$ \\
\hline$\leq 3$ & 88,89 & 0 & 88,89 & 0 \\
\hline $3,1-4$ & 0 & 22,22 & 11,11 & 0 \\
\hline $4,1-5$ & 0 & 77,78 & 0 & 22,22 \\
\hline $5,1-6$ & 0 & 0 & 0 & 55,56 \\
\hline$>6$ & 11,11 & 0 & 0 & 22,22 \\
\hline
\end{tabular}

\section{Results of Plants}

Statistical analysis showed that giving of plant growth regulators take effect on red onion crop yield, which included the number of tuber crop and wet tuber weight of crop. The effect of plant growth regulators on red onion crop yields is presented in Table 4. TSS red onion plants treated with coconut water ( $\mathrm{H} 4$ treatment) show the largest and larger number of tubers and tuber weight per plant, although not significantly different from red onion plants origin of TSS treated with a plant growth regulator solution of a mixture of auxin and gibberellin concentration of 200 ppm (treatment H2).

Furthermore, giving of coconut water is not only affects number of tubers and weight of tubers, but also trigger cleavage of tubers, so that the number of tubers per plant is increasing. TSS red onion plants treated with coconut water ( $\mathrm{H}_{4}$ treatment) show a lot of broken tubers, so that red onion plant that have tuber amount per plant more than 6 cloves reached 22.22\% (Table 5).

Table 6. Analysis of farming between red onion origin of TSS and tubers*

\begin{tabular}{|c|c|c|c|c|c|}
\hline \multirow[b]{2}{*}{ No. } & \multirow[b]{2}{*}{ Description } & \multicolumn{2}{|c|}{ Origin of TSS } & \multicolumn{2}{|c|}{ Origin of tubers } \\
\hline & & $\begin{array}{l}\text { Amount/ } \\
\text { Volume }\end{array}$ & Value (Rp) & $\begin{array}{l}\text { Amount/ } \\
\text { Volume }\end{array}$ & Value (Rp) \\
\hline \multirow[t]{20}{*}{1.} & Spending & & & & \\
\hline & a. Saprodi & & & & \\
\hline & - $\quad$ Seed & $3 \mathrm{~kg}$ & 7.500 .000 & $1.200 \mathrm{~kg}$ & 42.000 .000 \\
\hline & - Compost & $7.000 \mathrm{~kg}$ & 3.500 .000 & $5.000 \mathrm{~kg}$ & 2.500 .000 \\
\hline & - $\quad$ ZA & $300 \mathrm{~kg}$ & 450.000 & $300 \mathrm{~kg}$ & 450.000 \\
\hline & - $\quad$ NPK Mutiara & $500 \mathrm{~kg}$ & 4.750 .000 & $450 \mathrm{~kg}$ & 4.275 .000 \\
\hline & - Pesticides & 110 bottle & 19.250 .000 & 96 botol & 16.800 .000 \\
\hline & - Plastic dan bamboo & - & 2.500 .000 & - & - \\
\hline & b. Labor & & & & \\
\hline & - Cultivate soil+tractor & $45 \mathrm{HOK}$ & 2.925 .000 & 45 HOK & 2.925 .000 \\
\hline & - $\quad$ Seedlings & $35 \mathrm{HOK}$ & 2.275 .000 & - & - \\
\hline & - Soil bund + cannals & $66 \mathrm{HOK}$ & 4.290 .000 & $66 \mathrm{HOK}$ & 4.290 .000 \\
\hline & - $\quad$ Planting & $80 \mathrm{HOK}$ & 2.450 .000 & $65 \mathrm{HOK}$ & 2.275 .000 \\
\hline & - Ferlitization & $16 \mathrm{HOK}$ & 1.040 .000 & $16 \mathrm{HOK}$ & 1.040 .000 \\
\hline & - $\quad$ Pest control & $60 \mathrm{HOK}$ & 3.900 .000 & $50 \mathrm{HOK}$ & 3.250 .000 \\
\hline & - Watering & $15 \mathrm{HOK}$ & 975.000 & 15 HOK & 975.000 \\
\hline & - Weeding & $92 \mathrm{HOK}$ & 3.220 .000 & $82 \mathrm{HOK}$ & 2.870 .000 \\
\hline & - Harvesting and drying & $90 \mathrm{HOK}$ & 5.850 .000 & 65 HOK & 4.225 .000 \\
\hline & - Transport & $15 \mathrm{HOK}$ & 975.000 & $8 \mathrm{HOK}$ & 520.000 \\
\hline & Total of Spending & & 66.200 .000 & & 88.395 .000 \\
\hline 2. & Production **/Acceptance & $20.790 \mathrm{~kg}$ & 291.060.000 & $13.013 \mathrm{~kg}$ & 182.182 .000 \\
\hline 3. & Benefit & & 224.860 .000 & & 93.787 .000 \\
\hline 4. & B/C Ratio & & 3,397 & & 1,061 \\
\hline
\end{tabular}

Information : ${ }^{*}$ ) Excludes land lease

${ }^{* *}$ ) Dry weight / consumption and price in November 2017 Rp 14,500, - per kg

Table 4 shows that red onion plants from TSS treated with coconut water show the highest yield components. TSS red onion plants treated with young coconut water yield the largest 
number of tubers and tuber weight per plant. This is not separated by the growth of its performance. The red onion plant from TSS treated with coconut water has the most optimal vegetative growth pattern, where the largest number of leaves and stems and also the highest plant. If more the number of leaves, it is assumed that the photosynthesis process runs optimally, in which the results of photosynthesis will be partially stored in plant tissues, including tubers as food or energy reserves. Leaves are the place of the process of photosynthesis, where the results of photosynthesis on shallot plants are stored in tubers. So, more the number of leaves, the result of photosynthesis stored in tubers will be more and more. Therefore, the increasing number of leaves, the number of tubers of shallot plants per hill is increasing and followed by increasing of production.

Table 5 shows that red onion plant from TTS treated with coconut water (H4 treatment) yields tuber amount per plant more than 6 cloves as much as $22.22 \%$; the number of range cloves 4-5 as much as $22.22 \%$; and the number of range cloves 5-6 as much as $55.56 \%$. The results of this study indicate that the treatment of TSS with coconut water is able to solve the existing problems cultivated red onion by using TSS as a source of seeds. The problem faced on shallot cultivation with TSS is the limited number of tubers produced which are generally in the range of 1-2 tubers/cloves per plant. It is proven that the use of coconut water in TSS is able to produce onion tubers per plant more than 3 tubers/cloves.

\section{Farming Analysis}

Red onion cultivation business from TSS

which treated with young coconut water provides greater benefits than red onion cultivation with tubers as a source of seeds. Based on the analysis of red onion cultivation from TSS which treated with young coconut water can give a profit of Rp 224,860,000, - per hectare with $B / C$ ratio of 3,397 (Table 6 ). Profit derived from the cultivation of red onion from TSS which treated with young coconut water 1.75 times more than the profit derived from the cultivation of red onions from tubers which only reached $\mathrm{Rp}$ 93.787.000, - and B/C ratio of 1.061. Another benefits of shallot cultivation with TSS as a source of seeds is the cost of seed input is less compared with using tubers. If using TSS the procurement cost/purchase of seed is half less than the purchase cost of seeds in the form of tubers. That fact makes the production cost of red onion farming from TSS is relatively cheaper compared to using the tubers as a source of seeds.

\section{CONCLUSION}

1. Red onion plants from TSS which treated with coconut water produce the largest number of tubers and the biggest tubers weight per plant.

2. Coconut water can be used as a plant growth regulator for red onion cultivation by using TSS as a source of seed

3. Cultivation of red onion from TSS which treated with young coconut water can

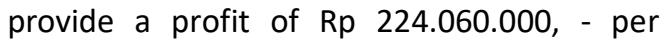
hectare with $\mathrm{B} / \mathrm{C}$ ratio of 3.397

\section{REFERENCES}

[1]. Suherman, R. dan R. S. Basuki. 1990. Strategi luas usahatani bawang merah (Allium cepa var. ascalonicum) di Jawa Bali. Tinjauan dari segi usahatani terendah. Bul. Penel. Hort. 18(3) : 11-18

[2]. Sunarto, A. D. H. Totok, S. Lukas, Suwarto dan F. Noor. 2004. Laporan penelitian peningkatan bawang merah (Allium cepa $\mathrm{L}$ ) Brebes tahap II. Fakultas Pertanian Unsoed. Purwokerto

[3]. Permadi, A. H. 1993. Growing shallot from true seed. Research Result and Problem Onion Newsletter for the Tropic. NRI United Kingdom. July 1993. Vol. 5 :35-38

[4]. Arisuryanti, T., B. S. Daryono, dan S. Hartono. 2009. Pengembangan metode skrining ketahanan tanaman bawang merah (Allium ascalonicum L) terhadap virus menggunakan RT-PCR. Laporan Hasil Penelitian. Fakultas Biologi. Universitas Gadjah Mada. Yogyakarta

[5]. Permadi, A. H. 1991. Penelitian pendahuluan variasi sifat-sifat bawang merah yang berasal dari biji. Bul. Penel. Hort. 2(4) : 120-131

[6]. Raduica, D. P. 2008. Research as the Biology, Technology and Use of Shallot (Allium ascalonicum). Hort. Magazine 8 : 250-257

[7]. Sumarni, N., E. Sumiati dan Suwandi. 2005. Pengaruh kerapatan tanaman dan aplikasi zat pengatur tumbuh terhadap produksi umbi bibit bawang merah asal biji kultivar Bima. J. Hort. 15(3) : 208-2014 
[8]. Sopha, G. A. 2010. Teknik persemaian true shallot seed (TSS). Balai Penelitian Sayuran. Lembang

[9]. Grubben, G. J. H. 1994. Contraints for shallot garlic, and welsh onion in Indonesia: a case study on the evolution of Allium crops in the equatorial tropics. Acta Horticulturae 358 : 333-339

[10]. Triharyanto, E., Samanhudi, B. Pujiasmanto dan J. Purnomo. 2013. Kajian pembibitan dan budidaya bawang merah (Allium ascalonicum L) melalui biji botani (True Shallot Seed). Makalah disampaikan pada Seminar Nasional Fakultas Pertanian UNS Surakarta dalam rangka Dies Natalis tahun 2013

[11]. Ridwan, H., H. Sutapraja dan Margono. 1989. Daya produksi dan harga pokok benih/biji bawang merah. Bul. Penel. Hort. 17(4) : 57-61

[12]. Rosliani, R., Suwandi dan N. Sumarni. 2005. Pengaruh waktu tanam dan zat pengatur tumbuh mepiquat klorida terhadap pembungaan dan produksi biji bawang merah (TSS). J. Hort. 15(3) : 192-198

[13]. Basuki, R. S. 2009. Analisis kelayakan teknis dan ekonomis teknologi budidaya bawang merah dengan biji botani dan benih umbi tradisional. J. Hort. 19(2) : 214-227

[14]. Putrasamedja, S. 1995. Pengaruh jarak tanam terhadap pembentukan anakan pada kultivar bawang merah. Bul. Penel. Hort. 27(4) : 87-92

[15]. Abbey, L. and R. Fordham. 1997. Growth and yield sensitivity of pre-bulbing and bulbing shallots to water-strees. Crop Research 14 : 307-313

[16]. Anonim. 2013. Panduan operasional penanaman benih bawang merah (TSS) menjadi umbi bibit dan umbi konsumsi berkualitas. PT East West Seed Indonesia. Purwakarta

[17]. Tiwery, R. R. 2014. Pengaruh penggunaan air kelapa (Cocos aucifera) terhadap pertumbuh-an tanaman sawi (Brassica juncea L.). Biopendix 1(1) : 83-91

[18]. Sujarwati, S. Fathonah, E. Johani dan Herlina. 2011. Pengaruh penggunaan air kelapa untuk meningkatkan perkecambahan dan pertumbuhan palem putri (Veitchia merilli). J. Sagu 10(1) : 24-28

[19]. Kristina, N. N. dan S. F. Syahid. 2012. Pengaruh air kelapa terhadap multiplikasi tunas in vitro, produksi rimpang, dan kandungan xanthorrhizol temu lawak di lapangan. J. Penelitian Tanaman Industri 18(3) : 125-134

[20]. Djumhari, E. 2011. Pemanfaatan air kelapa untuk meningkatkan pertumbuhan stek pucuk meranti tembaga (Shorea leprosula Miq.). J. Silvikultur Tropika 2(1) : 5-8 